$41(2) \mid 2012$

Varia

\title{
Markers of Masculinity: Phallic Representation in Moche Art
}

Señales de masculinidad: representaciones fálicas en el arte mochica

Les signes de la masculinité: les représentations phalliques dans l'art Moche

\section{Sarahh Scher}

\section{OpenEdition}

\section{Journals}

Electronic version

URL: http://journals.openedition.org/bifea/520

DOI: $10.4000 /$ bifea.520

ISSN: 2076-5827

\section{Publisher}

Institut Français d'Études Andines

\section{Printed version}

Date of publication: 1 July 2012

Number of pages: 169-196

ISSN: 0303-7495

\section{Electronic reference}

Sarahh Scher, "Markers of Masculinity: Phallic Representation in Moche Art », Bulletin de I'Institut français d'études andines [Online], 41 (2) | 2012, Online since 01 December 2012, connection on 26 November 2020. URL : http://journals.openedition.org/bifea/520 ; DOI : https://doi.org/10.4000/bifea. 520

\section{(c) $(1)$}

Les contenus du Bulletin de l'Institut français d'études andines sont mis à disposition selon les termes de la licence Creative Commons Attribution - Pas d'Utilisation Commerciale - Pas de Modification 4.0 International. 


\title{
Markers of Masculinity: Phallic Representation in Moche Art
}

\author{
Sarahh Scher ${ }^{*}$
}

\begin{abstract}
This paper examines the male body in Moche art as a locus for the ideological construction of gender. It proposes that the male body is characterized by vitality, violence, and potency, and that an aspect of this characterization may affect the conventions for representing the phallus. These conventions specifically refer to the erect, sexually potent phallus, even when a specific phallus is not depicted as erect. This mode of representation attempt to create a fixed state out of a temporary quality, by emphasizing the eternal performance of male gender.
\end{abstract}

Keywords: gender, semiotics, Moche, body, masculinity

\section{Señales de masculinidad: representaciones fálicas en el arte mochica}

\section{Resumen}

Este artículo investiga la representación del cuerpo masculino en el arte Mochica como un locus para la construcción ideológica del género. Se sugiere que el cuerpo masculino es caracterizado por la vitalidad, la violencia y la potencia, y que un aspecto de esta caracterización puede afectar a las representaciones del falo. Estas representaciones parecen referirse específicamente al falo erecto, con potencia sexual, incluso cuando este no está representado erecto. Este modo de representación intenta dar por perenne a un estado, en rigor, transitorio, enfatizando la eterna performance del género masculino.

Palabras clave: género, semiótica, Moche, cuerpo, masculinidad 


\title{
Les signes de la masculinité : les représentations phalliques dans I'art Moche
}

\begin{abstract}
Résumé
Cet article propose d'assigner au corps masculin, tel qu'il est représenté dans l'art Moche la fonction de lieu de la construction idéologique du genre. Le corps masculin serait caractérisé par la vitalité, la violence, et la puissance. L'un des aspects de cette caractérisation affecterait les représentations conventionnelles du phallus. Celles-ci renvoient toujours au phallus en érection, sexuellement puissant, même s'il n'est pas représenté en érection. Ce mode de représentation tente de figer une situation temporaire, afin de suggérer l'infaillibilité du genre masculin.
\end{abstract}

Mots clés : genre, sémiotique, Moche, corps, masculinité

As a subject of the artistic enterprise, the human body leads a paradoxical existence. The similarity of human bodies can create a situation in which only the addition of clothing can be said to give them meaning (Barthes, 1990: 258); in other conceptions, the body is itself a template for mapping meaning, framing notions about cosmology and humanity's place in the world (Bastien, 1978; Blom, 2005; Classen, 1993). The body can be shaped in ways which serve to create difference: cranial deformation, scarring, and tattooing are all forms of bodily modification which give information about the bodies that bear them, identifying groups of «us» and «them,» marking the differences within and between human populations. Some aspects of bodily adornment, while treated as elements of costume, require a modification of the body in order to be worn: ear, nose, and lip ornaments frequently require the re-formation of the flesh in order to be added to an ensemble. In some instances, the piercing of the flesh itself is a rite and a measure of both personal and group identity. The Inka ear-piercing ceremony, for instance, represented an important step that integrated the newly-pierced males into adult status and responsibility (Classen, 1993: 62). Through such rites, the flesh of the body is formed into that of a social being, becoming a member of the group through a process of inscribing signs on the body. The addition of elements of costume further places such signs on the physical form, which while less permanent than tattooing or piercing, nonetheless hold a great deal of meaning. This essay explores the contradictory construction of masculine bodies in the art of the Moche, a politically complex culture of Peru's north coast which flourished from approximately C.E. 1-850, as both performative and semiotic, and suggests that there may be more than meets the eye in the artistic convention for the male nude. I will begin with the argument for using both semiotics and the idea of performativity to find meaning in ancient art, and then examine gender as a lens for understanding the construction of identity. Finally, I focus on the production of masculinity, and how its uses and associations may have affected conventions of phallic representation that appear to suggest the practice of circumcision but may instead refer to a particular aspect of masculine performance. 
In this essay, I argue that the representation of the male body in Moche art participates in a subversion of the performative gendering described by Butler (1990), a subversion enacted by the ruling elites through the medium of artistic representation of elements of the Warrior Narrative, a linked set of individuals and actions which deals with the warrior's preparation for battle, the combat itself, his return from the battlefield as victor or vanquished, and the sacrifice of the defeated warriors in the Sacrifice Ceremony. Representation of ideal masculine appearance and action in effect creates a «performance» that exists outside of time, made permanent, and therefore stripped of any power or meaning outside of that conferred upon it by the semiotic system the state apparatus has constructed. This masculine ideal is represented in several forms and frozen performances, however I will note that an element of this transference from performance to sign takes place in the way in which the phallus is represented in Moche art. I use archaeologically excavated objects as well as museum pieces for this analysis. Focusing on the geographical and temporal distribution of warrior and phallic imagery, the majority of representations of nude captives destined for sacrifice come from Moche phases II and IV, roughly corresponding to 200-550 C.E., and come from The Moche heartland (the Chicama, Moche, and Virú valleys), with some pieces also found in the northern Moche site of Sipán1. The imagery of warriors in general, however, appears to have been a part of Moche iconography from its early stages.

\section{PERFORMANCE, SEMIOTICS AND GENDER IDENTITY}

Forming and negotiating identities is an important aspect of a culture's selfimage, and maintenance of identities is in many ways a maintenance of a culture. «Identities» are used here as social categories, not in the sense of an individual perception of the self, but rather as «characteristics... that are assigned and assumed by the group and others as a result of perceived differences from and similarities to others (Sørensen, 1997: 94)». These characteristics of identity are often constructed through signs, which are meant to proclaim allegiance to (and difference from) specific groups. Signs worn on or inscribed onto the body, in particular, are an effective way of conveying group identity. While clothing may be changed and can reflect shifting aspects of identity (such as the difference between informal clothing worn by a ruler in his or her chambers and the often unwieldy costumes of state functions), signs on the flesh are less likely to be changeable, and strive towards a permanence which costume cannot provide. This tension between the body and the clothing which covers it begins the struggle between the semiotic and the performative in the production of identity the body is, at least

1 Moche ceramics, especially those from the heartland and south, are usually grouped into five phases. developed by Rafael Larco Hoyle (1948), which are roughly sequential. However, phase styles may occur at different times in different sites, and in the north they are grouped into three larger periods which include Larco's Phase I and II in the Early Moche, Phases III and IV in Middle Moche, and Phase $\mathrm{V}$ in Late Moche. In the interest of brevity, I will use the relative chronology here. 
at first, seen as solid and permanent, bearing change only with effort and reluctant to change again, while costume is impermanent, allied with the temporal and ideas of performance. Butler identifies performance itself as a signification, and the performance of gender is related to the signification of a wished-for, coherent, ideal (1990: 46, 185). The «surface signification» of a nonexistent internalized «normative injunction» of gender is based in the requirements laid out by the socially constructed ideals of sex, ideals which are a «regulated process of repetition that both conceals itself and enforces its rules precisely through the production of substantializing effects (Butler, 1990: 191-193, 198)». Butler acknowledges that the prevalent cultural discourse seeks to control the performance of gender precisely by establishing ideals which are masked as normative and natural. This system would hold true no matter the number of gendered identities which were available in a culture and, as noted below, the Moche held different notions about the nature of biological sex than the binary system Butler was seeking to subvert. In the end, both the sexed body and the gendered surface are interpretations and performances, but performances which respond (whether in conformation or opposition) to an idealized, constructed, identity (1990: 185).

We must then regard the identities communicated by costume and bodily signs as part of a group's ideology2. By establishing categories of identity, the group or groups in control of the production of symbolic forms gain the ability to not only manipulate the relationships among the categories created by these identities, they also have the ability to represent the status quo or rather, an idealized version of it. Such represented ideals did exist in Moche society and seem to have been promoted over a significant period of time. When written records are available for a culture, the relationships among the body, formation of identity, and ideology can be more directly observed. It should however be borne in mind that even in literate cultures, the relationship between written ideals and actual practices is rarely equivalent. It is, however, between the written or represented ideals and the actual practice that the performative holds it power, for the performative is a series of instances, while the written and represented seek to construct the essential and prediscursive. When visual representation is what is left for our analysis, it should be regarded as existing as a system of signification in dialogue (or in contention) with the performative, even if the performative has long since ceased.

Both written and visual communication are circumscribed and shaped by the assumptions each culture has about the world. These assumptions are sometimes deliberately stated; at other times they are revealed through aesthetic and iconographic choices: what, as Panofsky says, a work of art «betrays but does not parade (1955: 14)». When written documents are not available, it is at least possible to propose certain attitudes based on the trends observed in the art. The way in which the signs of identity, such as costume and the body, are transformed into art offers a view into the way those identities were conceived, both explicitly

2 Defined here as «the ways in which the meanings constructed and conveyed by symbolic forms serve, in particular circumstances, to establish and sustain structured social relations...» (DeMarrais et al., 1996: 33). 
and as assumptions betrayed by the art. These assumptions begin to form a view of the «normative injunctions» of the culture, through the lens of those in control of the production of representations, as I will now explore.

In order to make sense of the conflicting points of reference present in the perception of the body, it is necessary to understand how bodies are negotiated socially as identities which exist in time, and then how those socially negotiated bodies are re-negotiated by the state apparatus, which has an interest in removing identities from time, rendering them permanent and beyond negotiation. While the Moche did not fulfill the requirements to be regarded as a state in the strictest sense, it is clear from archaeological evidence that the production of public discourse in the form of images was closely controlled by an elite, and that the vocabulary of this discourse formed an ideology that was shared among the elites of different polities ${ }^{3}$. The production of high-quality Moche ceramics appears to have been controlled by these same elite classes. There is archaeological evidence of the specialized production of fine ceramic objects bearing iconography, separate from the production of cruder and frequently undecorated wares (Chapdelaine et al., 1995: 184; Bernier, 2008: 34, 47-48; Jackson, 2008: 111). Close control over the production of art objects, often involving the use of molds, made a relative iconographic consistency possible. While different Moche polities manipulated the iconographic vocabulary and elements of artistic style (their parole) in order to assert independence and individuality (Cole, 2009; Donnan in press), the langue of the iconography maintained a remarkable amount of consistency between sites and served to create a unifying Moche identity (Castillo, 2007; DeMarrais et al., 1996; Donnan, 2010). This allows us to look at the construction of social categories through art as a relatively pan-Moche phenomenon, part of the ideological foundation which was the basis of «Mocheness». Much of the data for this essay comes from a broad sampling of Moche ceramic art from museums and archaeological projects, a corpus which is intended to approximate a langue of Moche art4. Here, I shall address the general relationship of the state/ruling elite and the individual within the polity without diverging into discussions of interpolity political diplomacy.

Gender categories are a basic element of identity construction in Moche iconography. While sometimes regarded as strictly dyadic, in reality Moche art creates a spectrum of sex and gender, with masculine and feminine poles and mixed or ambiguously-gendered identities in between them which appear to be based in notions of ambiguously or dually-sexed bodies (Scher, 2010: 245284). Masculine gender identity is used here as a case study of the way secondary meanings are formed in Moche art, and how those meanings are integrated into

3 «Elite» is a deliberately loose term, and here refers to the stratum or strata of Moche society that controlled the religious and political institutions of the society.

4 The corpus was collected for dissertation research, and constitutes approximately 1400 ceramic representations of human figures, in two and three dimensions. While a balanced representation of Moche polities was desired, the database is heavily weighted toward the Southern Moche sphere of influence. This is acknowledged in my findings. 
the ideology how representation is an attempt to subvert the performative and solidify it into the semiotic in the service of the polity.

While gender is generally regarded as a social identity built upon biological sex, Butler (1990: 46, 91-92) notes that the body straddles the categories of language and biology, arguing that there is no a priori sexed body. Rather, internal and external organs are interpreted as sex, and from that the gender of the individual is socially constructed on the «fact» of that interpretation. Butler continues with her now famous argument that gender is a performance, something which is to be aimed at but never completely achieved rather than a fact, and that the «incessant action» of gender performance is the basis for our understanding of the categories «male» and «female» (1990: 112). These performances are monitored by society, which enforces them through the erasure of and violence against those who do not fit the established categories. In her desire to subvert the categories, and the binary system which is both their source and their result, Butler turns to the idea of performance as itself capable of subversion. Rather than performing the actions dictated by the binary system, performance can create categories which do not conform to «male» and «female», and which furthermore do not carry with them the notions of «compulsory heterosexuality» that travel with them (1990: 46, 75, 156).

Butler, as a modern philosopher, is focused mainly on the intersection of these interpretations of biology and the language used to express them, as well as the language used to either erase or enact violence against those outside the categories. Language, in the modern world, exists in a parallel set of states: the written and the spoken. But, as Butler analyzes both forms in Excitable Speech (1997) it becomes clear that as a literate culture, we are most familiar with words that, even when spoken, can be transcribed and replicated as a written expression. It is necessary, then, to examine the differences between our current vantage point for observing gender categories and the vantage point available for cultures which did not use a written language, and who are no longer available to give their opinions orally. In this sense, objects are acting as language, and that is all we have in terms of direct Moche communication.

While Moche did not have a written language, they produced a great deal of art, which featured the human body with greater and greater frequency as the culture progressed. The major surviving media are ceramic vessels, metalwork, and architectural wall decoration. This study focuses mainly on ceramics, the largest group of extant representations. While there were at least three major political divisions within the Moche area, the artistic style and iconography maintain a fair amount of similarity across them. As noted above, different polities would select from the larger iconographic vocabulary, but all the polities worked with the same iconographic langue, which their selections referred to and in fact relied upon to ground their meaning. Moche art is unusually naturalistic and detailed, describing a large range of human and supernatural identities involved in a number of narrative themes. However, it has also been noted that this breadth of depiction is not all-inclusive: there are many areas of 
daily life which are not depicted, as well as others which are represented out of proportion to their relevance to day-to-day reality (Donnan, 1976). Moche art depicts three realms of existence: the world of living humans (what modern western tradition considers the «real» world), the land of the dead, and the world inhabited by supernatural beings, both zoomorphic and anthropomorphic. The land of the dead, populated by animated skeletons, is not necessarily the same as the world of the supernaturals, as the two groups rarely seem to interact within the representations. Both groups, however, easily pass into the world of humans, and it is possible humans may pass into their worlds. I will here focus on the Moche representation of the human world, and the human male body as it is presented in the art. By focusing solely on human representation, I focus on the way in which Moche artists, and those directing them, perceived and reproduced their world, and how their assumptions about and manipulations of human masculinity are reflected in the art they produced. However, it becomes clear that even representations of the human world can have connections to the supernatural, through narrative associations with themes that unite them.

Choosing and maintaining a standard iconographic style and subject matter effects a selection from the multiplicities of human existence, picking a single version from an «endless number of possibilities» and repeats an iconic version of events, actions, and appearances which represents the ideal form of being (Barthes, 1990: 6). These ideal representations and categories are then broadcast through their distribution, not only to the living, but also to the dead, by inclusion in grave goods (Carr, 1995: 158; Donley, 2008: 121). Communicating the idealized version of existence to the spirit realms as well as the lived world extended the influence of Moche ideology both through time and across dimensions of existence. What the iconography of Moche art conveys to us is the state's production of identities both its own and that of its subjects. It is the official discourse of the Moche elites, controlled though the workshops and the modes of distribution of images.

The intersection of verisimilitude and ideology in Moche art has been tackled by Jeffrey Quilter, who noted the conflict between interpreting Moche art as both a «[record of] daily life and a symbolic code (2002: 162)». His concern represents a growing conflict in Moche studies, as the extensive work done on the iconography is aligned with greater and greater amounts of archaeological data, which can often contradict conclusions based in iconography alone. Elizabeth Benson recently addressed the changes that have occurred in Moche studies as more and more cultural material is scientifically excavated, and the ways in which the world represented by the iconography is separate from the world outlined by archaeological data. She notes that the iconography can often perform as a «gloss» of more complex ideas, and that there is ample archaeological evidence for rituals and activities not expressed in the art (Benson, 2008: 2-13), further confirming Donnan's assessment of Moche art as selective in its topics.

There is, however, a limit to the extent archaeology can «correct» the conclusions of iconographic analysis. While Quilter sees a dilemma in considering Moche art both verisimilar and symbolic, this contradiction can to some extent be resolved 
by acknowledging Moche art as selecting from daily life in order to create its code. A culture's art is not limitless in scope, it is circumscribed culturally and reflects the attitudes and expectations of that culture (Kubler, 1975: 766). Benson says as much when she concludes that Moche art depicts «core meaning (2008: 6)». Moche art is both reflective of daily life and symbolic, in that select elements of daily life are used in a symbolic manner. Interpreting Moche daily life using representations presented in the art, then, offers some problems. However, by approaching these representations as a semiotic system, it is possible to understand the construction of social identities while acknowledging that these identities are ideological constructs, meant not to represent «real life» but to render the ideal natural through the use of images based in the lived world. This approach cannot allow us to understand the individual life of any one Moche person, rather it allows an understanding of the mental constructs which were held as the ideals of identity: the ideology, or even propaganda, that promoted the world as it «should» be, rather than as it necessarily was. In this usage, Benson's «gloss» is more politically understood as a revision, or re-vision, of the Moche world. The iconography created a selective view of Moche life, one which has led researchers astray in some cases precisely because it was intended to be an image of Moche life that created reality rather than reflected it and the archaeology now contradicts that reality because it could not be controlled in the same manner as the iconography, it reveals the performative of people's lives.

This is where Butler's ideas intersect with the theories of semiotics. Butler's performativity relies on the idea of a repeated action, which is enacted perforce through time and implies all the vicissitudes that accompany the temporal, such as change, degradation, and failure. In Butler's view, the performative is acting counter to the semiotic, which represents the established categories and the way in which they are expressed. However, semiotics is itself called to bear in her description of elements of performance: that performance itself is expressed through signs and their meanings, and can seek to contradict the established discourse of binary gender. However, in Moche art what we see is the state attempting to exert control over performance by representing it. Through representation of ideal gender performance, gender identities in art achieve a level of fixedness which cannot exist in the lived world, just as other aspects of ideal identity are selected and perpetuated through iconographic repetition. A representation in ceramic, metal, or adobe mural exists indefinitely in time, creating a kind of eternal performance which is meant to approach the essential. By representing the ideals of gender, what is created is a «body» of representations that perpetuates and reinforces the idea of an a priori, essential gender. It creates a langue of gender, against which all individuals are a parole, and an emulation of the ideal.

As an example, the kneeling warrior in Figure 1 is a frozen performer covered in signs and himself turned into the signification if an ideal. The warrior is even depicted in action - the bent left knee, hands clasping the mace, and turned head all imply movement, and with it existence in time-. However, this warrior will never «finish» his performance: he will not stand, will not fight, will not age. His action is an illusion, created through the choice to depict him in a captured moment. 
That moment then, through its representation in ceramic, is extended infinitely in time. This warrior now becomes any warrior; he cannot assert any individuality, he is reduced to the elements of the iconography which have been selected by the artists and the elite who control them. And so the warrior, with his weapon, his elaborate helmet, nose ornament and earspools, his tunic and kilt with representations of metal appliqués, and his elaborate wrist cuffs, is no longer in motion, performing, living as an individual. He is an iconic representation of the idealized performance the state desires from the warrior, and so he becomes a sign masquerading as a performance. His body is represented adorned with the sartorial signs of his identity —and in this case, signs that indicate not only warrior identity but high status even within that category - and presented in an unchanging form so that any individuality this warrior may have exerted through performance in time is gone. This is even clearer in the vessel in Figure 2, which depicts a scene of combat. The two figures which face each other are again in a frozen moment: a face-to-face confrontation towards the end of the conflict, as the warrior on the left has seized the hair of the warrior on the right. Both figures are rendered with a minimum of detail, enough to show that the two figures are wearing typical warrior costume, and that the victorious combatant is the one holding a mace. This scene is replicated exactly on the other side of the vessel, and this vessel is itself duplicated, with another from the same mold excavated at the same time. The action, therefore, is repeated in representation, but does not extend forward or backward in time. It reduces the combat and the combatants to iconographic images, making the performance a signifier of idealized warrior nature.

Figure 2 - Moche vessel depicting two warriors in combat, possibly Phase III. The figure on the left grasps his opponent's hair in a gesture signifying victory

Image courtesy of the Phoebe A. Hearst Museum of Anthropology and the Regents of the University of California (4-2932)

Photo: Sarahh Scher

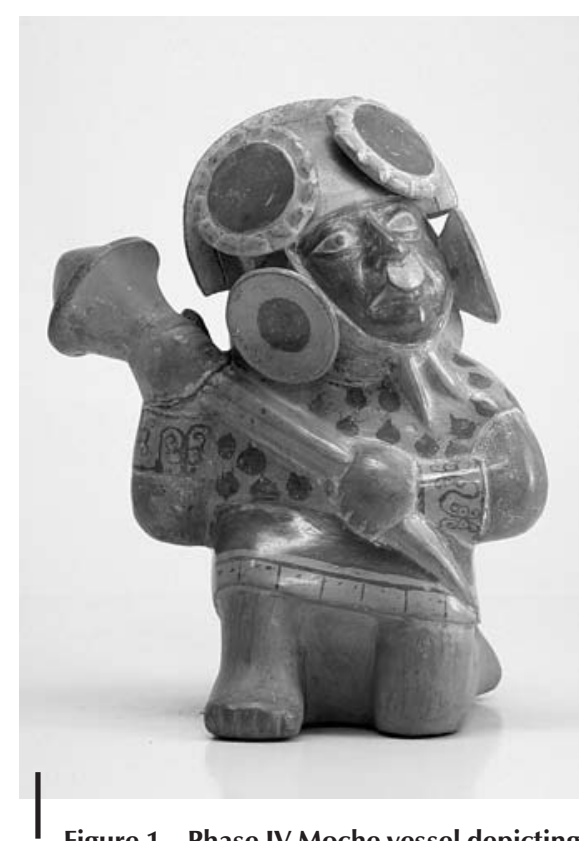

Figure 1 - Phase IV Moche vessel depicting a kneeling warrior in full regalia, carrying a mace

Image provided by the Museo Arqueológico Rafael Larco Herrera, Lima, Perú (ML001569)

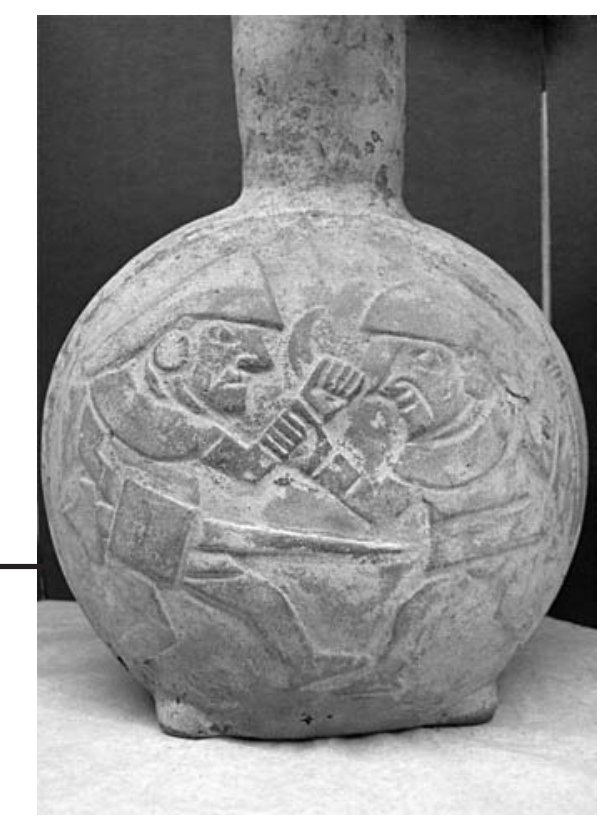


By creating images which serve as the text of state discourse, the ruling elites selectively represented the appearance and actions not of individuals but of identities. These identities are ideal creations that specifically seek to subvert the performativity of daily life by fixing it in time and rendering it permanent. However, the representations are presented as contradictory things - as fixed performances - that act as an attempt to make the ideal appear natural. While the «incessant action» of Butler's performativity exists in time and is subject to change, the representation of a moment in an ideal performance has the effect of perpetuating that moment in time, creating a performance which never falters, never fails, and persists in a state which approaches permanence, the very thing performance is supposed to negate. In Moche art, the state strikes at the heart of performativity's power by turning the performance itself into a sign. By controlling the representation of gender, as well as other aspects of identity, the state can create the illusion of an a priori identity to which individuals must conform. Like Butler's notion of the erasure or denial of bodies which do not fit into the binary gender system of the modern Western world, so the Moche state apparatus proffered, through representation, ideal bodies which were to be taken as templates for individual existence. Those which did not conform to these identities were, in effect, erased in the Butlerian sense. (There are for example no images of farmers in Moche art, only symbolic, often deified, harvester figures, while there are ambiguously-gendered figures who have a spiritual significance, albeit a lowerstatus one). Semiotics allows us to interpret the visual language of the idealized performance as it was presented by the state. What we see in the representation of warriors is perfect action suspended in time - a performance co-opted by the state and removed from the possibility of subversion-. It creates an official visual text which presents the ideal male identity, one which serves the state as both warrior and as sacrificial offering.

\section{WARRIORS AND MASCULINITY}

The construction of masculinity in Moche art revolves around the Warrior Narrative. As Donnan \& McClelland (1999: 69) note, while individual elements of the Narrative may have been present in Phases I and II of the Moche ceramic styles, with individual actors and elements represented prior to the blossoming of complex scenes, it is during Phase III that the Narrative begins to take iconographic shape, and it flourishes from that point until the end of Phase V, as Moche culture itself comes to an end. Warriors and references to warfare form a considerable portion of Moche art, perhaps as much as 60 percent of all representations (Donnan, 2010: 53). This theme is represented across the Moche subdivisions, as warriors, their accouterments, and references to the Sacrifice Ceremony figure heavily in imagery from San José de Moro and Sipán in the north, at Huaca de la Luna and Huaca del Sol in the heartland, and the murals at Pañamarca in the south. It would seem, therefore, that the Narrative, as an ideological trope, was present at the beginning of Moche culture and spread with it as part and parcel of 
Moche identity. However, different areas of the Moche world chose to highlight or ignore elements of the Narrative. In the north, it is clear at San José de Moro that the High Priestess and the associated Tule Boat Woman were emphasized over warrior imagery, although the weapons bundle and images of warriors still exist (Cole, 2009; McClelland \& Donnan, 2007). At Sipán, the warrior identity was heavily emphasized, especially the Warrior Priest and his role as officiant of the Sacrifice Ceremony. South of the Moche heartland, at Pañamarca, the Priestess and warriors are both depicted, associated with the Sacrifice Ceremony. The heartland sites of Huacas de la Luna and del Sol as well as Huaca El Brujo feature prominent warrior iconography in the architecture, and Huaca de la Luna has yielded a great number of warrior ceramics. At present, the greatest number of provenanced representations of nude captives comes from Huaca de la Luna. As this study is most concerned with the representation of the phallus, it will concentrate on examples from the northern and heartland areas, since there are no excavated pieces from the southern region in the research corpus, and no published examples that have come to my attention. The sites specifically represented in the corpus are from Sipán, Huaca de la Luna, and El Brujo. Examples from museum collections without provenance were also collected. It is clear that elements of the Warrior Narrative were still important in the south, regardless of the lack of phallic representations. The captive prisoners studied for this study are dated from Phases III and IV, with one Phase V vessel too damaged to accurately determine whether the phallic imagery is the same as in III and IV. While there were no Phase I or II prisoner representations encountered, it should be noted that there is a Phase I piece excavated by Donnan at Dos Cabezas (Donnan, 2007: 127), and that there are Phase I and Phase II-III pieces in the Museo Larco (ML004282 and ML004235) which depict the phallus with the same conventions that will later characterize the phalluses of captives.

All stages of the Warrior Narrative are characterized by conventionalized representations and standardized costumes, reflecting a well-entrenched cultural meaning, and use the same conventions across artistic media. These conventions change little over time, with the warrior costume already well-developed by Phase I. Moving forward through the chronology, what changes most is the available decoration of already-extant elements of costume: more metal plating, a greater number of attachments to the helmet, nose ornaments, and decorative backflaps. While there are a small number of so-called «portrait vessels» which appear to depict physiognomically distinct individuals wearing warrior's helmets (Donnan, 2004: 17), they are limited to the central Moche area and to Phases III and IV. Their limited temporal and geographical scope may be reflective of a political strategy that would still have a foundation in the identity constructed by the more common generic representations as described here. The Warrior Narrative itself is represented across the Moche area, and the majority of warrior depictions are on the level of the ideal and the conventional. Warriors are overwhelmingly treated as exemplary constructs, rather than individuals. The Narrative also includes conventionalized depictions of the nude male body, which become part of the warrior identity, and hold equally important cultural messages. 
Warriors can be shown individually (often on one bended knee), and in combat with other warriors (Figs. 1 and 2). Combat, as it is an artistically complex theme, is usually depicted in low relief or in scenes painted on the surface of vessels, and therefore becomes more prevalent in phases IV and $\mathrm{V}$ with the blossoming of fineline painting (Donnan \& McClelland, 1999: 69, 75). Single warriors are represented in fineline painting, low relief, and as effigy vessels sculpted in the round. The costume elements worn by warriors are heavily standardized: they wear conical helmets with a flap down the back of the neck, short, sleeveless tunics, and a loincloth, sometimes covered by a kilt. The kilt and the loincloth are iconographically interchangeable, and the loincloth is frequently visible underneath the kilt. A belt is occasionally visible, often with the addition of bells or a backflap - a piece of metal, shaped like the sacrificial knife or tumi, which sometimes has additional decoration-. Warriors also carry a club or mace with a distinct biconical shape, and usually a shield as well. Leg paint is a further element of warrior costume, usually consisting of a «sock» of paint on the lower half of the shin and foot, with a stripe above and a round or diamond-shaped spot on the knee (Fig. 3). This costume is represented in varying degrees of sophistication in sites throughout the

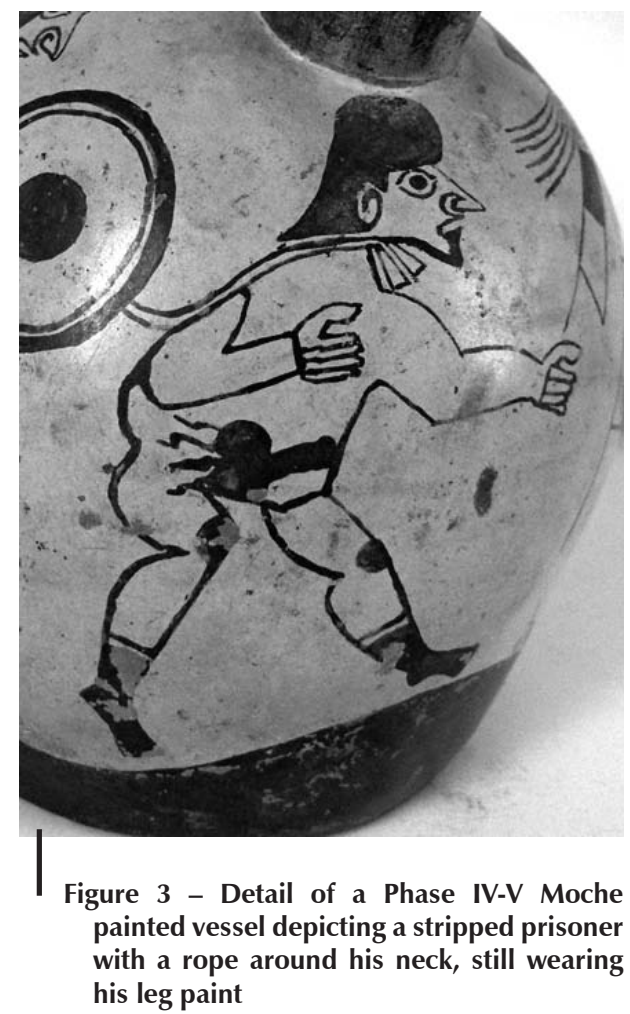

Image courtesy of the Museo Arqueológico Rafael Larco Herrera, Lima, Perú (ML001749) Photo: Sarahh Scher
Moche area, and the consistency of depiction indicates a cultural element, reinforced through its repetition in representation on the works of art produced under the auspices of the elites. The standard costume also persists in time, even as the artistic style shifts to a greater number of two-dimensional depictions in the later Moche phases. While the relative unity of warrior costume depictions distinctly separates warriors from the rest of the Moche iconographic population, the physical body of the warrior itself is not distinguishable from other male bodies. That is, it is neither more nor less muscular, tall, or otherwise physically distinguished from non-warrior male bodies (indeed, without the distinguishing signs of sexual organs, unclothed men's and women's bodies are the same in Moche art). The characterization of masculine gender lies in the actions performed by a body that, without its signifying costume, is otherwise indistinguishable from other bodies. The separation and identification of the warrior body from the common body is founded on the semiotics of costume and represented action. It is this semiotic system which begins to create the re-presentation of a performance co-opted by the state and reified in the official texts of ceramic, metal, and adobe mural art. 
It is important to note that while the costume of the warrior identifies him, it is his actions that define him. While warriors are sometimes depicted sitting, they are more often shown kneeling, running, and fighting. By depicting the semiotic body in action, this key element of performance is introduced to the identity of the warrior, fitting him into the Butlerian notion of performativity at the same time that performance is standardized, controlled, and reproduced under the rule of elite ideological concerns. The creation of the warrior ideal in Moche art is achieved mainly through physical action of the semiotically identified body, generating an ideal predicated upon vitality and strength. These actions then become part of the signification of the warrior, an inherent part of its meaning. It is an example of the way in which action and performance are transformed into signs by means of the production of images.

The significance of Moche depictions of warfare has been deeply debated (Lau, 2004; Quilter, 2002), and while there are scenes which depict foreign combatants engaged with Moche warriors, I will concern myself here with those which represent warriors who both wear Moche costume. Quilter and others have noted that it is frequently difficult to determine status differences between individual warriors (2008: 223). While the costume elements of two combatants may differ, there is often little to indicate that one is of substantially higher status than another, and these same costume differences do not seem to indicate who will be victorious in the engagement5. While it has been surmised that the lack of discernible difference may be due to symbols of rank unknown to us (Quilter, 2008: 223), it is also possible that the relative iconographic parity of Moche warriors was part of an ideal based upon the combat of equals. If we return to the idea that Moche art selects from real life in a way that is symbolic, the «real»combat of Moche warriors, in representation, becomes an illustration of the warrior ideal. In essence, debates over whether Moche warfare was «ritual» or «real» are of no consequence in the art, as the representation of warfare focuses solely on the ideal, and makes all represented warfare «ritual» and, consequently, also an ideological construct subject to the manipulation of the state.

Defeated warriors, as the source of blood for the Sacrifice Ceremony, are carefully fashioned within the Moche langue to emphasize their vitality. This is accomplished mainly through the Warrior Narrative, as noted above. By setting up the ideal of combat as a contest between equals, the prisoner who is the result of that combat is constructed as a fitting sacrificial victim by virtue of his ability to fight his opponent with valor. This equality is emphasized by the near-ubiquity of maces as the weapons used in the coup de grâce. The mace, unlike other weapons shown in Moche art, requires that the victor and victim be within a short distance of each other. Slings, spears, and darts are all capable of killing from a distance, but they are not depicted as the instruments of a warrior's defeat, even though they are

5 The sole exception to this is a particular face-paint design which Bourget (2006) identifies with the pupae of muscoid flies and the decay of sacrificial bodies. This pattern is rarely depicted on warriors engaged in combat. 
sometimes shown carried by warriors. The construction of the warrior as strong and brave is significantly strengthened by the portrayal of the mace as the weapon of choice. Whether for supernatural or political purposes, the ideal of conduct and combat for a Moche warrior carried the same significance: to best an equal in hand-to-hand combat, to knock off his helmet and grasp his hair, signifying not only the victor's superiority but also an entrance into liminality for his victim as the vanquished warrior lost his semiotic costume.

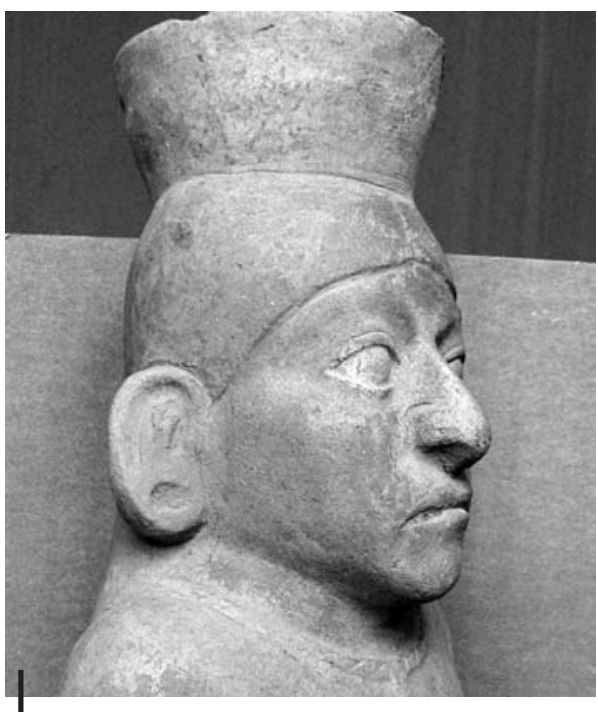

Figure 4 - Detail of a Phase III Moche prisoner effigy, with indications of ear holes where ornaments would have been worn

Image courtesy of the Proyecto Arqueológico Huacas del Sol y de la Luna (PU-792)

Photo: Sarah Scher

Erica Hill has written extensively on the importance of liminality in the depiction of defeated Moche warriors, a state of being which made them excellent conduits for communication with the supernatural world $(1998 ; 2000 ; 2003)$. This liminality begins with the initial removal of the helmet, one of the main distinguishing marks of warriorhood, and indeed basic maleness, in Moche art - prisoners are the only males in Moche art depicted without some form of headcovering - Once defeated, the warrior's remaining elements of costume were taken from him, and are often shown carried by his victor6. The defeated warrior is left stripped of his sartorial signifiers, with the occasional exception of his leg paint, and with the addition of a rope around his neck (and sometimes his wrists), which ushers in his new identity as prisoner. The costume which once defined him has been transformed into a bundle of weapons and costume elements held by his conqueror, signifying both his defeat and the victor's conquest. Even his ears have been stripped of their ornaments, leaving the empty holes as a reminder of their absence (Fig. 4). As a liminal figure, the body of the prisoner thus reduced to itself is subject to semiotic modification throughout his remaining existence, further promoting the state's ability to create meaning on the body.

This semiotic manipulability is especially seen in depictions of prisoners who are adorned with elements of costume. While most prisoners and sacrificial victims are represented as nude, some prisoners are depicted wearing garments that are associated with ritual, especially a tunic covered with metal plating, which Benson has identified as an attribute of the Owl God (1982: 183-185). The prisoners wearing the plated tunic become associated with this deity, and were perhaps specifically dedicated and sacrificed to him, or represented him in the reenactment

6 This panoply of gathered accouterments is part of the characteristic ceramic iconography of San José de Moro, creating the presence of warriors and their ideals even in a polity that more overtly emphasizes other aspects of Moche ideology. 
of a myth (Benson, 1982: 183-185). In addition to these costumed captives, there are also nude prisoner effigies with similar plate-like designs painted or incised on the torso, creating the presence of a garment or deity attribute on the body (Fig. 5). The traces of the garment are inscribed on the represented body of the prisoner, making his flesh conform to the needs of ritual. These painted or incised tunics are liminal garments, in that they exist only somewhat in the physical sense. The essence of the garment (the distinguishing artistic representation of the plaques) has been placed on the body like a real garment, but rather than a solid, shiny, and sonorous material object, the tunic is now composed solely of images. The desired malleability of the prisoner's body is played out in the actual pliability of the clay effigy, once again creating an ideal that has the appearance of a temporal performance while being fixed in time and subject to the will of the elite. This malleability, and the removal or replacement of clothing, does not take away a warrior's vitality. Rather, in defeat his vitality is now expressed in other ways, primarily through the representation of the phallus. Even prisoners dressed in the Owl God tunic can have an exposed phallus, further indicating not only the symbolic nature of their costume (lacking in the loincloth of the fully-dressed warrior), but also emphasizing that aspect of the male body revealed by defeat.

\section{THE PHALLUS IN MOCHE ART}

In Moche art the phallus is depicted in two main themes: on prisoners and in representations related directly or metaphorically to sexual activity. Prisoner imagery flourishes from Phase III onward and is present throughout the Moche area, in ceramic, metal, and adobe mural forms. Sexual imagery begins in Phase I but appears to be limited to the heartland and the ceramic medium, although Kirkpatrick (1992: 97) describes a metal representation of a supernatural being engaged in intercourse with a human woman from Sipán. There are too few pieces with secure provenance to state the limits of sexual representation conclusively. While there is a tradition of sexual imagery on the Peruvian north coast, Moche art is unique in the quantity and variety of its representations. That same variety also emphasizes the ability of sexual contact to bridge between the human and supernatural worlds, often through the potency and fertile force of male sexuality (Scher, 2001: 39-45, 72-89). Sexual interaction between the

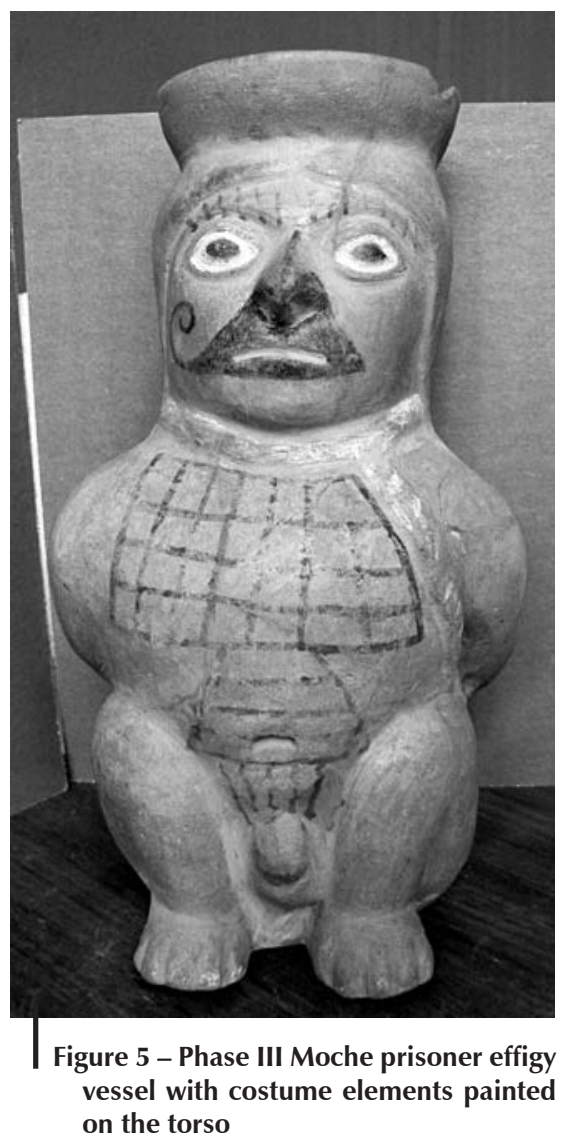

Image courtesy of the Proyecto Arqueológico Huacas del Sol y de la Luna (PU-991)

Photo: Sarahh Scher 


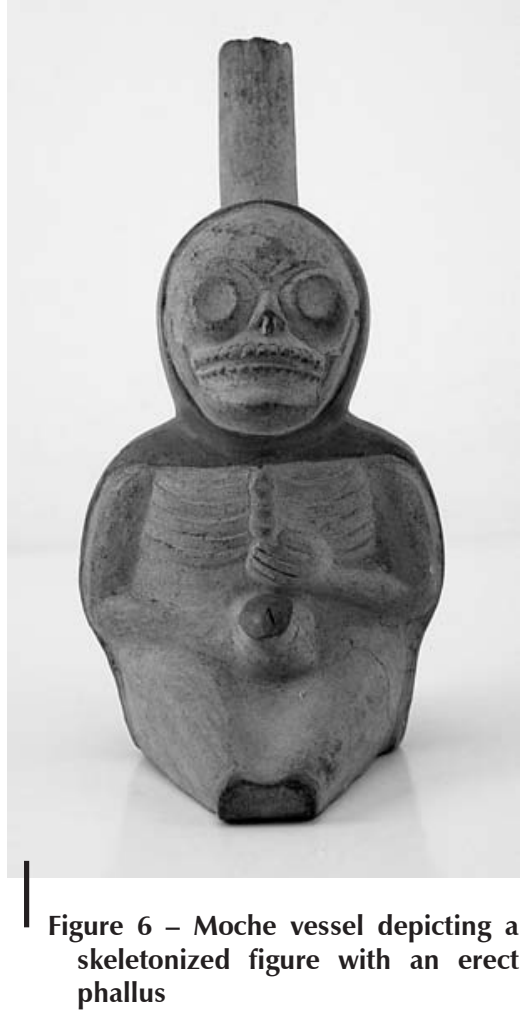

Image provided by the Museo Arqueológico Rafael Larco Herrera, Lima, Perú (ML004321) worlds is effected in two types of representations: human women with skeletal men, and a human woman with a supernatural figure. In the former, living women kiss, fondle, and are fondled by dead males, who are characterized as having skeletal heads and torsos (with empty eye sockets and visible ribs), yet who have fleshly and seemingly functional (usually erect) phalluses (Fig. 6). Steve Bourget has pointed out that the color contrast between light (often white) and dark (usually red) slip in these ceramic representations accentuates the relationship between dead and vital matter. The skeletal bodies of the male figures are painted in a cream or white slip, but the glans of the phallus is highlighted with red. Bourget notes the association of red with blood, life, and vitality, illustrating the concept of a male potency which exists beyond death, and beyond the dissolution of the rest of the body (2006: 108). That the Sacrifice Ceremony centered on the extraction and consumption of the prisoners' blood circles back to the confluence of sacrifice and sexual potency. The interaction between humans and non-human supernaturals is carried out in an iconographic theme often referred to as The Deity Making Love. In it, a human woman lies on her back, with an anthropomorphic supernatural figure on top of her. Human and zoomorphic companions attend this coupling, watching from a proximate distance or waiting in separate structures.

In both cases, it is the sexual potency of the male that penetrates into the human world from the supernatural. This establishes male potency -and the phallus itself - as liminal, with the ability to cross between worlds and to have an effect on the human inhabitants of this plane of existence. This depiction also characterizes women as receptors of male vitality, with the ability to make contact with other worlds by allowing their passage into them. This receptivity is tied metaphorically with the idealization of agricultural processes, in which the water that rushes down from the mountains (associated with semen and the active, fertilizing sexuality of the male) activates the passive fertility of the alluvial plains, characterized as female (Scher, 2001: 79-82). A vessel from the collection of the Kinsey Institute for Sex, Gender, and Reproduction Research (Fig. 7) clearly associates the erect phallus with the mountains. Joan Gero notes (2004: 20) that all the activities depicted in Moche sexual representations, while they appear to depict a wide range of actions, in fact center on the primacy of male orgasm. Women's sexual pleasure is simply not a matter for representation - it is subject to erasure within the iconography-. While Gero focuses on the implications of gendered power this imagery calls forth, this masculine focus also emphasizes the importance of male vitality, as it is more important for 
the female partner to be penetrated and receive the masculine energy through his sexual gratification than for the penetration itself to lead to pregnancy. Woman is «fertilized» even in situations which are not by Western definitions fertile (Weismantel, 2004: 497), and so these sexual representations focus on the power of the phallus and of masculine fertility, a power which can become an element of exchange between the human and supernatural worlds as well as a template for gendered relations in the human world. The same vitality present in the water from the mountains and from male sexual energy is passed by way of the prisoner's blood to the spirit world through the sacrifice, just as his semen is passed to women in sexual scenes (and in both instances, drinking the vital fluid is a valid method of transfer). While there are few well-provenanced sexual representations, three scientifically-excavated pieces from Huaca de la Luna (Fig. 8) depict a male figure seated on a throne, while a female figure performs fellatio on him. The scene conforms to standard iconography in many respects, but has been constructed so that the woman's head can move on a pivot, like a bobblehead, to «perform» the act in perpetuity. The pieces are all nearly identical, indicating the use of molds in their creation. In the piece illustrated here, the phallus has broken off, but it reveals the fact that the woman's mouth, which would have bobbed back and forth on the phallus, is painted with a ring of cream slip, emphasizing the transfer of semen from the male to the female in this act. The male wears a tunic decorated with a step pattern often associated with ritual structures and mountains, and with his hand held in a gesture Donnan refers to as the halffist (1978: 151). The half-fist is associated with the mountains and scenes of sacrifice conducted on them, and Bourget (2006: 123) also relates this to the phallic element of mountains and their association

Figure 8 - One of three nearly identical Phase IV ceramic pieces excavated at Huaca de la Luna, depicting a woman performing fellatio on a man who is seated on a bench or throne

Image courtesy of the Proyecto Arqueológico Huacas del Sol y de la Luna (PT-007)

Photo: Sarahh Scher

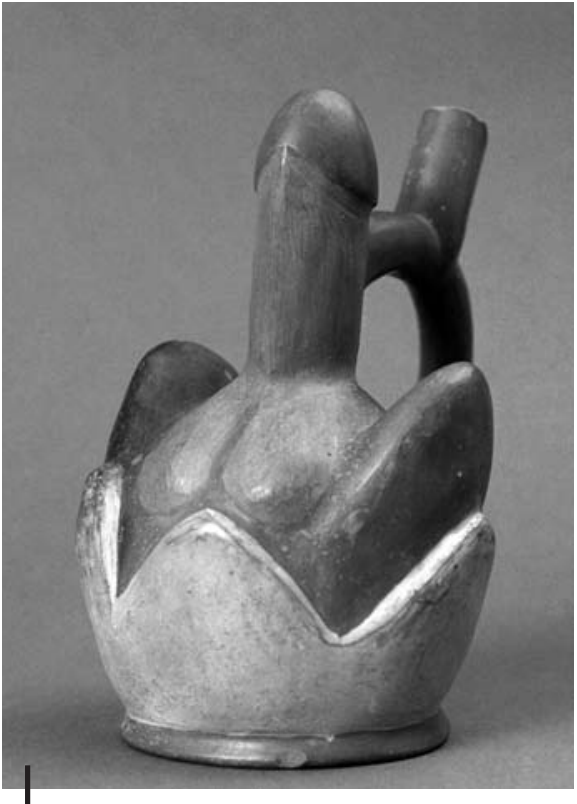

Figure 7 - Phase III Moche vessel depicting an erect phallus rising from a stylized mountain range

Image provided by the Kinsey Institute for Research in Sex, Gender, and Reproduction, Inc (A 862K E003.1)

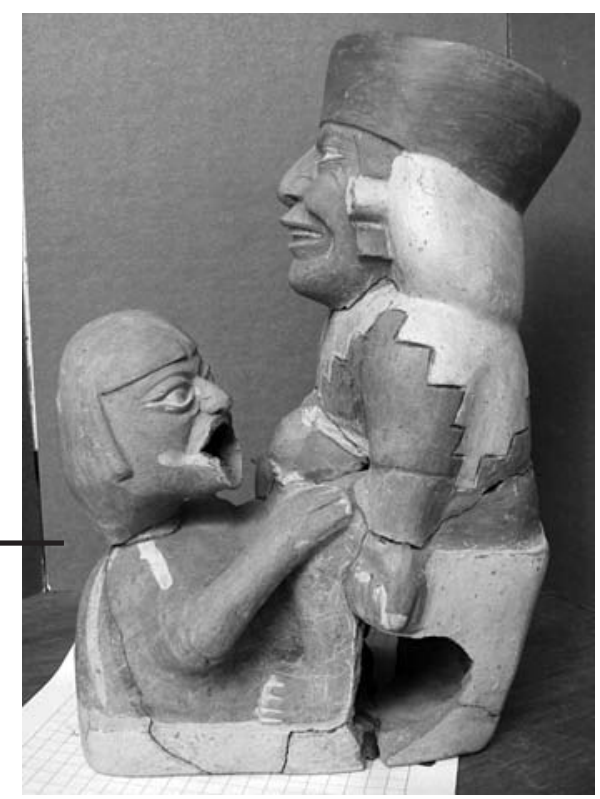


with male fertility. Here, as an excavated piece, we have the representation of the primacy of male fertility, the association of semen with the mountains, and the use of molds to create a repetition of imagery. In addition, we have the unusual aspect of a representation that mimics action, that is meant to seem performative but, again, as with all representations, is merely the appearance of performance. As we can see, while the female figure can be compelled to perform her action indefinitely, yet there is also the sign of the act's completion — the cream slip around her mouthwhich conflates the actions performed in time into a single signifier, creating an ideal performance which never ends, and yet is paradoxically also completed. In this way, the act and its significance are taken out of time, made to have an existence which is contradictory to the idea of performance while mimicking it.

Many representations of Moche prisoners depict the phallus as partially or fully erect, linking them directly to the iconography of sexual representation. The large, public representations in adobe relief from Huaca Cao Viejo of prisoners being paraded in preparation for the sacrifice also depicts the phallus as erect (Fig. 9). Several direct causal associations between sacrifice and erections have been postulated, including the appearance of an erection caused by bloating of the sacrificed corpse (Bourget, 2006: 124) and an autonomic reaction caused by trauma to the spinal cord during the sacrifice itself (Scher, 2001: 64-65). A recent article by Bussmann \& Sharon (2009: 12) postulates that the ulluchu, a fruit seen depicted in scenes of sacrifice and also closely associated with warriors, may be Guarea sp., a plant genus which may have the property of causing both hallucinations and sexual arousal when ingested. If this is the case, it is possible that prisoners were deliberately given ulluchu as part of the sacrificial ritual,

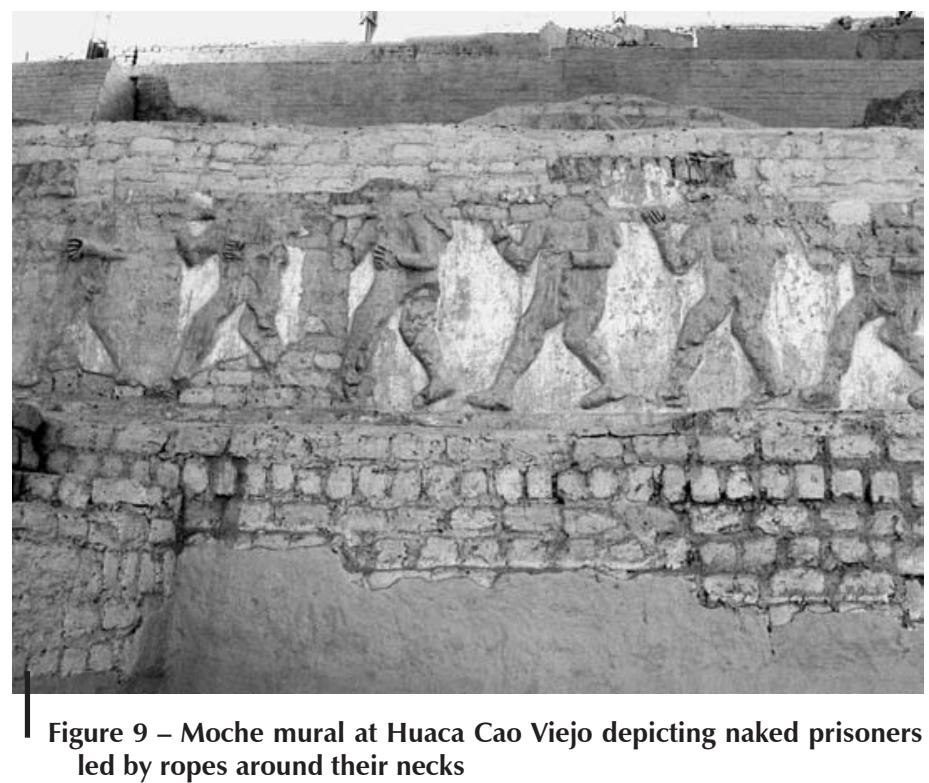

Photo: Sarahh Scher 
further manipulating their bodies to achieve the desired performance as required for the occasion creating a performance which conformed to the ideal, manipulating the flesh of individual bodies to participate in the ideological construct that the artistic canon had created for them. Any individual performance was concretized and idealized by its reproduction in art, a reproduction which literally stripped away any individualizing signifiers and promoted the «canonic generality» of the category.

As noted, representations of skeletonized male figures with living, functioning phalluses indicate a belief in the persistence of male vitality and fertility past the barrier of death (Fig. 6). This connection between the erect phallus and sacrificial death may be prefigured in the representations of prisoners with erect phalluses. The presence of women as assistants in depictions of sacrifice, as well as companions of prisoners before and after their sacrifice (Fig. 10), is symbolically part of this sexual dynamic. Whether prompted by actual physical causes or not, the iconographic emphasis on the erect phallus in scenes of sacrifice links the rite to notions of male potency. This sexual potency, combined with the general bodily potency of martial prowess, is what is being offered to the supernatural world through

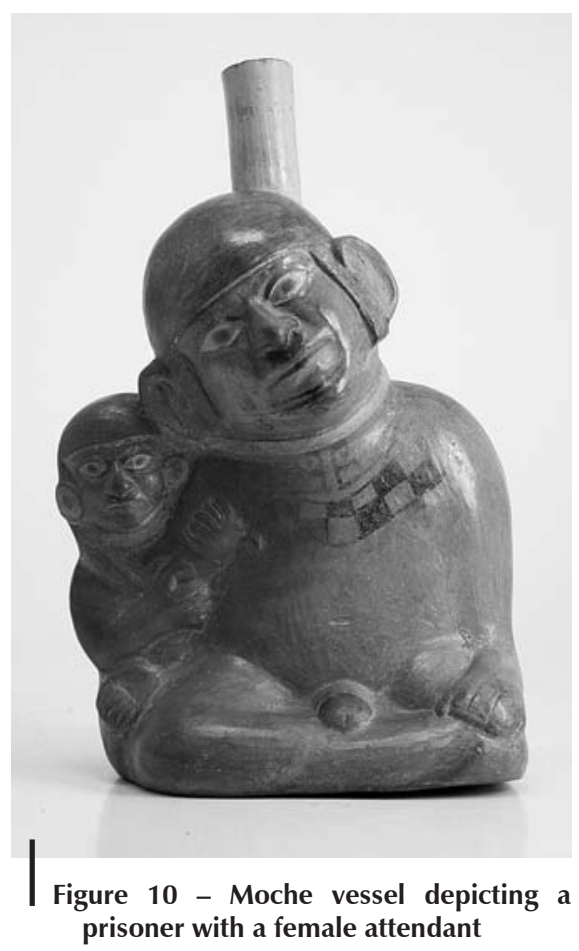

Image provided by the Museo Arqueológico Rafael Larco Herrera, Lima, Perú (ML002039) the sacrifice of defeated warriors. It is this construction of the sacrificial victims as spiritually powerful figures, who are marked as worthy warriors before their defeat and as containers of liminal male potency during the sacrificial ritual, that leads to the possibility that this matrix of masculinity is visible in all depictions of the phallus, not solely those which are characterized by an erection.

The integral importance of warriors to the iconography of sacrifice makes their definition of manhood supremely important to Moche ideology. Without warriors there is no sacrifice, and without sacrifice there is no bond of reciprocity with the spirit forces of nature, the gods, and the ancestors. Christopher Donnan likens Moche warriors to medieval knights, members of the elite who incorporated ritualized violence into their identity (2010: 51). However, unlike knights, these warriors' sacrificial deaths were absolutely necessary to the religious ideology of their society. This holds regardless of the actual numbers of victims sacrificed by the Moche. It must be reiterated here that not only the presence but also the profound numerical ubiquity of Warrior Narrative imagery indicates that the Narrative, with its emphasis on blood sacrifice, was a central point of ideology and an idealized performance that existed separately from the actual commission of the ritual within a single Moche polity or lifetime. Its perpetuation in representation allowed for the appearance of the repetition or persistence of the performance outside of time, 
irrespective of how often it was carried out in the world of the living. This allowed the implications of the sacrifice - the power structures that created an elite who had the ability to conduct these sacrifices, and in turn reap the rewards of being the interlocutors between the worlds - to exist outside of the actual performance of the ritual. By repeating it in representation the sacrifice becomes continuous, and so the power that adheres to the celebrants is also continuous. It is part of the co-optation of performance by the state, in this case creating the appearance of an «incessant action» through the duplicated representation of what may or may not be singular events, representations which themselves are idealized and made to conform to ideological needs.

I propose that there is also a possible semiotic reference to sexual potency and the identity of masculinity even in depictions of prisoners who do not have an erect phallus. The phalluses of captured prisoners,

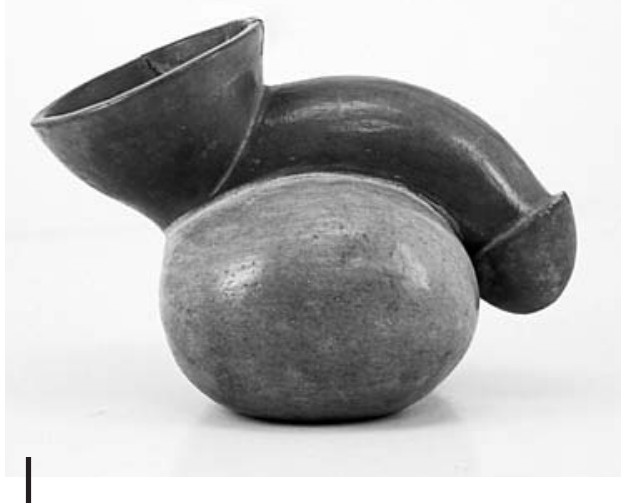

Figure 11 - Moche phallic effigy vessel

Image provided by the Museo Arqueológico Rafael Larco Herrera, Lima, Perú (ML004204) both standing and walking, are depicted with the glans visible, even when it is clear that the phallus is not in a state of excitement. Representations of the disembodied phallus exhibit the same appearance (Fig. 11)7. This would, of course, be normal if the Moche practiced the body modification of circumcision, but there is no evidence other than these depictions to suggest that they did. While it is impossible to prove conclusively whether the Moche performed this modification, it is useful to explore the possibility of a more complex second-order meaning for these phallic representations, and the ideological implications for the construction of masculinity in Moche art.

\section{CIRCUMCISION IN ETHNOGRAPHIC AND HISTORICAL SOURCES}

Circumcision is a form of body modification which has been practiced by many societies at various times and in geographic locations, and as such it would not be unreasonable to expect or assume its presence in the Andes. However, it is important to note that at the time of the Spanish arrival in Peru circumcision was an object of profound conflict in Spanish society, to the point where it should have been something worth remarking upon were it encountered. The Spanish, influenced as they were by the long wars of the Reconquista, held a conflicted attitude towards circumcision. On one hand, the Circumcision of Christ and its celebration in the Catholic liturgical calendar were important aspects of Spanish Christian life. The veneration of the Circumcision as the first utterance of Jesus'

\footnotetext{
7 For more examples, see Bergh (1993).
} 
name was especially important to the Jesuits, who had a strong presence in Spain and the Spanish Americas (Göttler, 1997: 798). But while the event from the life of Christ was revered, Christians themselves no longer performed circumcisions. It was believed that the fulfillment of the Law that was embodied in Christ made His circumcision the last. The continuance of the practice by Jews and Muslims therefore separated them from Christians on a profound level, and embodied a rejection of Jesus as the Messiah (Pardo Tomás, 2003: 170, 172). Some Spanish Christians even argued that the rite the Jews and Muslims performed was not the same as that from Abrahamic times, and was, in fact, a deceit of the devil (Darst, 1979: 302). The association of Jews with circumcision led some medical works to suggest that Jews were born circumcised, as though the preservation of their practice had resulted in an «acquired racial trait (Pardo Tomás, 2003: 173)». Circumcision was the mark of those not within the fold of the Church, and indeed crypto-Jews in Spain eventually ceased performing circumcision, as it was an indelible mark which made detection inevitable (Beusterien, 2004: 362-363). While most Spanish Jews refrained from the practice, Muslims continued with it, and in Spanish eyes the two groups were to some extent conflated in this regard. The scrutiny under which circumcision fell meant that an unusual foreskin could be construed as evidence of the practice, and required further investigation if noted on a child at baptism (Fernández García, 1995: 489). Circumcision was so fraught a custom, so closely tied to anxiety about conversos and Judaizing, that a Christian male who had to have surgery which would affect the foreskin

«did not hesitate to summon physicians, surgeons, neighbours and relatives around his bed to act as witnesses, before a notary, of the intervention he was about to undergo so that all would certify with their signature that the intervention was carried out for medical reasons and no others») (Pardo Tomás, 2003: 178).

Such deep concern with circumcision would make its absence from Spanish records nearly impossible were it practiced in the Americas at the time of contact. The subject of circumcision was indeed raised during the lengthy intellectual debate about the origins, nature, and rights of the peoples of the New World. The theory that the «Indians» were Jews, the descendants of the Lost Tribes of Israel, was addressed by Father Bartolomé de las Casas in his Apologética historia sumaria (written in the late sixteenth or early seventeenth century), where he dismissed the possibility, saying that while circumcision had been reported in the Yucatán, it was nowhere else practiced, and the Jews were «known» to closely guard their cultural practices (Adorno, 1992: 826). Making such an assertion would have been difficult had there been more than one New World culture known to be practicing circumcision at the time of the debate, as it would have quickly been part of his opponents' counter-argument. Indeed, such a highly charged observance would have been something remarked upon and likely suppressed by the Spanish had it been encountered in the Andes. Circumcision is not mentioned among the many and lengthy interrogations included in Pérez Bocanegra's Ritual formulario (1631), a guide to confession for priests with native parishioners in Peru, while dealing 
with many other aspects of sexuality and its relationship to native religious beliefs. Pedro de Cieza de León, as well, in his remarks upon the sexual practices of the north coast peoples, does not mention circumcision, while listing a number of other «sinful» acts related to gender and sexuality (Cieza de León, 1985: 224, 269). An examination of the depiction of naked indigenous males in Guaman Poma's illustrations (1992) also reveals phalluses which appear uncircumcised, something this chronicler of everyday Andean life would have drawn attention to were it an important fact or point of persecution for the native populations ${ }^{8}$. That the lack of circumcision was something so commonplace as to remain unmentioned seems to indicate that it was not a contested field between the Spanish and natives in the Andes.

Of course, all this is circumstantial evidence and does not conclusively demonstrate that circumcision was not performed by the Moche, who had long ceased to exist by the time these authors made their observations. However, in light of the fact that the cultural norms of the Andes, and indeed the Americas in general, would seem to be weighted against it, it is interesting that the Moche chose to depict the phallus as they did, with the glans exposed. An uncircumcised penis normally sheathes the glans within the foreskin when the phallus is not in a state of arousal. However, sexual arousal and the erection of the phallus pull back on the foreskin, exposing the glans. It may be that the exposed glans depicted in Moche art is a reference to this state of sexual excitement. In a society which does not practice circumcision, all phalluses depicted with an exposed glans would be referents of sexual excitement and, by association, an implicit reference to the fertilizing force made explicit in scenes of sexual interaction, and perhaps regarded as an essential component to the ideal of masculine gender. There are phalluses which clearly depict the exposed glans and those which do not, but the latter are often small figures in two-dimensional representations, which may not have had the space to elaborate the depiction. More significantly, there are no depictions in Moche art which clearly show the foreskin covering the glans. By way of comparison, a fairly realistic double-spouted phallic vessel from the north-coast Vicús culture (which existed from roughly 800 B.C.E. - 200 C.E.) appears to show one phallus as erect, with the glans visible, and the other as somewhat flaccid, with the appearance of a foreskin covering part of the glans (Fig. 12). Such disembodied representations emphasize the fertilizing power of the organ as a sign in itself.

\section{THE PHALLUS AND MASCULINITY IN MOCHE ART}

If the conventions of phallic representation do indeed refer to a temporary condition rather than to a modification of the body, then the phallus is constructed as a sign of active fertility even outside of explicitly sexual representations. The vitality and potency that makes a warrior the perfect sacrificial offering is strengthened within this convention of depicting anatomy, and becomes part of

\footnotetext{
8 See, for example, illustrations 308 and 499.
} 
the definition of masculinity in Moche art. The phallus, through its representational associations with the actions of sexual excitement, maintains these associations even outside of explicitly sexual scenes. By marking all phalluses with the appearance of the erect phallus, all phalluses participate in this vitality. It is, in a Butlerian sense, a performance of male fertility and vigor rendered permanent, a transient physical state made eternal through both the endurance of the depiction in time and the shared quality among all phalluses. All depicted phalluses carry the sign of the erect phallus, and so all participate in the ideal of the erect and potent phallus. By making this aspect of the phallus the conventional mode of representation, the elites in control of art production co-opted the performance of masculinity, wrested it from the individual and made it general, took it from the temporally contingent and gave it the

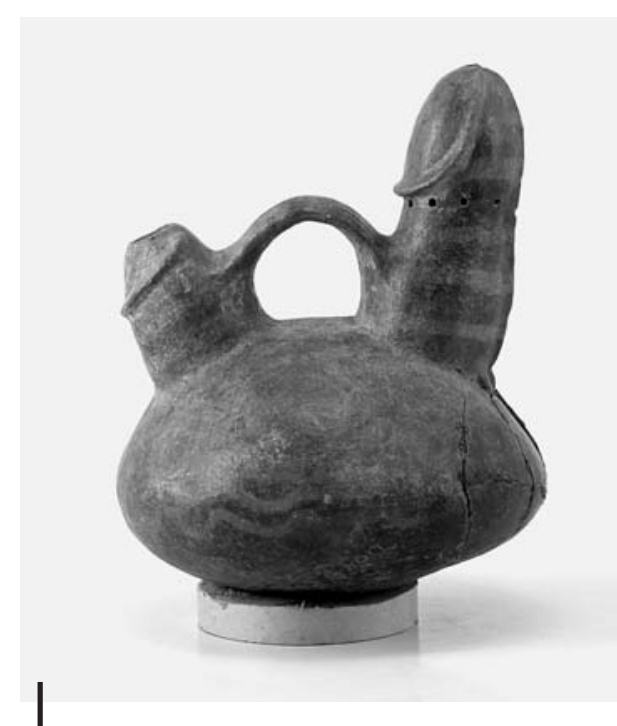

Figure 12 - Vicús phallic-spouted vessel

Image provided by the Museo Arqueológico Rafael Larco Herrera, Lima, Perú (ML004433) appearance of the natural, the permanent, and the essential. All bodies which did not conform to this reified performance were, effectively, erased from the official discourse of masculinity, vitality, and the sacrificial reciprocity that sanctioned the power of those performing the sacrifice.

This signified conception of the male body, like many conventions in Moche art, is far more invested in the ideal than in the individual9. Emphasis on type over individual is especially evident in disembodied representations of the phallus, such as a vessel in the collection of the Museo Arqueológico Rafael Larco Herrera (Fig. 11), the Kinsey vessel in Figure 7, and a copper spear-thrower end piece from Loma Negra, at the far northern reach of the Moche sphere of influence (Metropolitan Museum of Art, 1979.206.1320). This idealized generality is also evident in the lack of individuality seen in most Moche depictions in general. While, as noted, there were physiognomic portraits produced in the Moche area, these were limited in both time and location and are the exception, rather than the rule, of Moche representation. Furthermore, it should be noted that these «portrait vessels» are only of the head; the rest of the body is ignored even in this circumscribed foray into representational individuality. This is the "canonic generality» to which Barthes refers in his description of the models in French fashion (1968: 7), meant to be a vehicle for the social meanings of their costume rather than individuals. When, as in the case of the Moche, the costume is composed of conventional elements rather than changeable fashion, the costume

9 A similar interest in the group over the individual is also evidenced in the depiction of female and child bodies. See Scher clothing power. 
begins to accrue meanings that are intensified with each representation, each presentation of the acts and ideals associated with the identity to which the image is tied. By repeatedly creating representations of warriors and prisoners that conformed to a set of narrow characteristics, the Moche elite were creating both canon and generality. Repetition created the sense of the natural, of the a priori, and so became canonical. With the exception of the brief foray into portraiture noted above, the artistic conventions for depiction of bodies and faces assured generality. In almost all instances, Moche art depicts types, rather than singular individuals, and this includes the male nude.

These male nude conventions are currently found mostly in the Moche heartland, but the spear-thrower end piece noted above, as well as prisoners represented in the ceramic contents of the tombs of Sipán, show that there was representation of these ideals, albeit in a limited fashion, in the north. Ceramic prisoner effigies with conventional phallic representations were found in ceramic repository 1 as well as Tomb 1 (the Tomb of the Warrior Priest), and it is clear that these effigies were produced by mold in the same fashion as the majority of the ceramics at Sipán. They are, like most of the ceramic caches, of relatively mediocre quality, showing little finish after removal from the mold. Despite this lack of attention to artistic quality, there is attention in at least half of the pieces to the depiction of the phallus, which clearly shows the same exposure of the glans seen in the more technically sophisticated pieces from the Moche heartland10. Even with the lack of finish characteristic to these pieces, it was apparently important enough to distinguish on occasion. As further excavations are carried out in the southern reaches of Moche influence, examples may be found there as well, and it will be possible to determine exactly how deeply a part of the langue this particular convention for depicting the male body was.

\section{CONCLUSION}

The arguments above strive to not only parse the meaning of the phallus in Moche art, but to also investigate the cultural institutions which formed the representations that were being examined. This exploration is meant to highlight the sophistication of the Moche elites in their manipulation of imagery and ideology, a sophistication that appears to have been adopted by independent polities as Moche influence expanded. For while these polities were asserting their individual identities through iconographic selection (such as the female imagery found at San José de Moro), their selections were intimately tied to the comprehensive iconography (the langue). Their selections were in dialogue with the langue, were founded in it, and were referring to it with each parole. In this way, the common «Mocheness» that was assumed with the adoption of the ideology was asserted and maintained, while still allowing for individuation among polities. Thus we have differing artistic choices, such as the primacy of 
metals in Sipán and the sophisticated ceramics of Huaca de la Luna, or the distinctive fineline style developed at San José de Moro, while still being able to identify their subjects according to overarching themes and mythologies. The Sacrifice Ceremony itself seems to have been used as an iconographic referent throughout the Moche world, whether as the murals at Pañamarca, the identities assumed by the rulers of Sipán and the Priestesses of San José de Moro, or the prisoner effigies found at Huaca de la Luna. The depiction of the stripped prisoner is a subset of this referent, and seems to have been limited to the heartland and north from Phase III onward, but it builds on the ideal of the warrior and of the potent phallus which had been in place before then. As the emphasis on sacrifice increases in the iconography in these areas, the linking of the prisoner's phallus with the potent phallus becomes clear, and becomes the articulation of a point of both theology and ideology. The appearance of the phallus as permanently linked to the state of arousal then becomes not just a matter of idealized identity, it becomes a matter of political power. The methods by which this idealized identity was represented and perpetuated by the polities that chose to make it part of their parole can be viewed as intentionally subverting the transient, performative aspects of identity in favor of a concretized and seemingly a priori sameness, one which suits the needs of a political structure dependent on the relationship sacrifice created with the supernatural world.

Again, while it is currently impossible (and may never be possible) to conclusively prove that the Moche did not practice circumcision, the ethnographic evidence and lack of Spanish concern with the topic make it likely that this was the case. In light of this, it is important to consider the important meaning attached to the way the phallus was represented, and the implications this had on the idealization of manhood and masculinity in Moche ideology. It also brings to the discussion the place of the elites in creating these ideals, and the methods by which, even in what is not strictly a state society, a state apparatus-like control over the iconography of ideology was wielded.

\section{Acknowledgments}

Funding for this research was generously provided through a Fullbright-Hays grant and Emory University's Laney Graduate School. My deep thanks to the institutions which granted permission for image use in this article; to the article's reviewers, who significantly strengthened this piece; and to Delinda Collier for her editorial generosity.

\section{References cited}

ADORNO, R., 1992 - Censorship and Its Evasion: Jerónimo Román and Bartolomé De Las Casas. Hispania, 75 (4): 812-827.

BARTHES, R., 1968 - Elements of Semiology, 112 pp.; New York: Hill and Wang.

BARTHES, R., 1990 - The Fashion System, 351 pp.; Berkeley: University of California Press. 
BASTIEN, J. W., 1978 - Mountain/Body Metaphor in the Andes. Bulletin de I'Institut Français d'Études Andines, VII (1-2): 87-103.

BENSON, E. P., 1982 - The Well-Dressed Captives. Baessler-Archiv, Neue Folge, 30: 181222.

BENSON, E. P., 2008 - Iconography Meets Archaeology. In: The Art and Archaeology of the Moche: An Ancient Andean Society of the Peruvian North Coast (S. Bourget \& K. L. Jones, eds.): 1-22; Austin: University of Texas Press.

BERGH, S. E., 1993 - Death and Renewal in Moche Phallic-Spouted Vessels. RES, 24: 7894.

BERNIER, H., 2008 - Especialización Artesanal En El Sitio Huacas De Moche: Contextos De Producción Y Función Sociopolítica. In: Arqueología Mochica: Nuevos Enfoques (Actas Del Primer Congreso Internacional De Jóvenes Investigadores De La Cultura Mochica, Lima 4 Y 5 De Agosto 2004) (L. J. Castillo, H. Bernier, G. Lockard \& J. Rucabado Yong, eds.): 33-52; Lima: Fondo Editorial de la Pontificia Universidad Católica del Perú, Instituto Francés de Estudios Andinos.

BEUSTERIEN, J., 2004 - Lope De Vega's. Auto Sacramental De La Circuncisión De Cristo: A Focal Pont of Anti-Semitism in Seventeenth-Century Spain. Hispanic Review, 72 (3): 357-374.

BLOM, D. E., 2005 - Embodying Borders: Human Body Modification and Diversity in Tiwanaku Society. Journal of Anthropological Archaeology, 24: 1-24.

BOURGET, S., 2006 - Sex, Death and Sacrifice in Moche Religion and Visual Culture, 272 pp.; Austin: The University of Texas Press.

BUSSMANN, R. \& SHARON, D., 2009 - Naming a Phantom: The Quest to Find the Identity of Ulluchu, an Unidentified Ceremonial Plant of the Moche Culture in Northern Peru. Journal of Ethnobiology and Ethnomedicine, 5, n. ${ }^{\circ}$ 8. Disponible en: http:// www.ethnobiomed.com/content/5/1/8.

BUTLER, J., 1990 - Gender Trouble: Feminism and the Subversion of Identity, 172 pp.; New York: Routledge.

BUTLER, J., 1997 - Excitable Speech: A Politics of the Performative, 200 pp.; Routledge.

CARR, C., 1995 - Mortuary Practices: Their Social, Philosophical-Religious, Circumstantial, and Physical Determinants. Journal of Archaeological Method and Theory, 2 (2): 105-200.

CASTILLO, L. J., 2007 - Moche Politics in the Jequetepeque Valley: A Case for Political Opportunism. In: San José De Moro Archaeological Program: Readings: 2-36; Lima: Pontificia Universidad Católica del Perú.

CHAPDELAINE, C., KENNEDY, G. \& UCEDA, S., 1995 - Activación Neutrónica en el estudio de la producción local de la cerámica ritual en el sitio moche, Perú. Bulletin de I'Institut Français d'Études Andines, 24 (2): 183-212.

CIEZA DE LEÓN, P. de, 1985 - La Crónica Del Perú; Madrid: Historia 16.

CLASSEN, C., 1993 - Inca Cosmology and the Human Body, 214 pp.; Salt Lake City: University of Utah Press.

COLE, E., 2009 - A Northern Moche Paradox: The Absence of Warfare Imagery in the San Jose De Moro Fineline Substyle. In: Abstracts of the Society for American Archaeology, 74th Annual Meeting, 81; Atlanta, GA: Society for American Archaeology.

DARST, D., 1979 - Witchcraft in Spain: The Testimony of Martín De Castañega's Treatise on Superstition and Witchcraft (1529). Proceedings of the American Philosophical Society, 123 (5): 298-322. 
DeMARRAIS, E., CASTILLO, L. J. \& EARLE, T., 1996 - Ideology, Materialization, and Power Strategies. Current Anthropology, 37 (1): 15-31.

DONLEY, C., 2008 - Late Moche Burials in San Jose De Moro. In: Arqueología Mochica: Nuevos Enfoques (Actas Del Primer Congreso Internacional De Jóvenes Investigadores De La Cultura Mochica, Lima 4 Y 5 De Agosto 2004) (L. J. Castillo, H. Bernier, G. Lockard \& J. Rucabado Yong, eds.): 119-129; Lima: Fondo Editorial de la Pontificia Universidad Católica del Perú, Instituto Francés de Estudios Andinos.

DONNAN, C., 1976 - Moche Art and Iconography, 146 pp.; Los Angeles: UCLA Latin American Center, University of California Press.

DONNAN, C., 1978 - Moche Art of Peru: Pre-Columbian Symbolic Communication, 206 pp.; Los Angeles: Museum of Cultural History, University of California.

DONNAN, C., 2004 - Moche Portraits from Ancient Peru, 188 pp.; Austin: University of Texas Press.

DONNAN, C., 2010 - Moche State Religion: A Unifying Force in Moche Political Organization. In: New Perspectives on Moche Political Organization (J. Quilter \& L. J. Castillo, eds.): 47-69; Washington, D. C.: Dumbarton Oaks Research Library and Collection.

DONNAN, C., in press - Moche Substyles: Keys to Understanding Moche Political Organization.

DONNAN, C. \& McCLELLAND, D., 1999 - Moche Fineline Painting: Its Evolution and Its Artists, 319 pp.; Los Angeles: UCLA Fowler Museum of Cultural History.

FERNÁNDEZ GARCÍA, M. A., 1995 - Criterios Inquisitoriales Para Detectar Al Marrano: Los Criptojudíos En Andalucía En Los Siglos XVI Y XVII. In: Judíos, Sefarditas, Conversos: La Expulsión De 1492 Y Sus Consecuencias (Á. Alcalá, ed.): 478-502; Valladolid: Ambito.

GERO, J. M., 2004 - Sex Pots of Ancient Peru: Post-Gender Reflections. In: Combining the Past and the Present: Archaeological Perspectives on Society: Proceedings from the Conference «Pre-History in a Global Perspective» Held in Bergen, August 31stSeptember 2nd 2001, in Honour of Professor Randi Haaland's 60th Anniversary (R. Haaland, T. Oestigaard, N. Anfinset \& T. Saetersdal, eds.): 3-22; Oxford, England: Archaeopress.

GÖTTLER, C., 1997 - Nomen Mirificum. Rubens' Beschneidung Jesu Für Den Hochaltar Der Jesuitenkirche in Genua. Zeitsprunge: Forschungen zur Frühen Neuzeit (1997): 796-844.

GUAMÁN POMA DE AYALA, F., 1992 - El Primer Nueva Corónica Y Buen Gobierno (J. V. Murra, R. Adorno \& J. Urioste, eds.), 1173 pp.; México, D. F.: Siglo Veintiuno.

HILL, E., 1998 - Death as a Rite of Passage: The Iconography of the Moche Burial Theme. Antiquity, 72: 528-538.

HILL, E., 2000 - The Embodied Sacrifice. Cambridge Archaeological Journal, 10 (2): 317 326.

HILL, E., 2003 - Sacrificing Moche Bodies. Journal of Material Culture, 8 (3): 285-299.

JACKSON, M. A., 2008 - Moche Art and Visual Culture in Ancient Peru, 232 pp.; Albuquerque: University of New Mexico Press.

KIRKPATRICK, S., 1992 - Lords of Sipan: A Tale of Pre-Inca Tombs, Archaeology, and Crime, 256 pp.; New York: Morrow.

KUBLER, G., 1975 - History: Or Anthropology: Of Art? Critical Inquiry, 1 (4): 757-767.

LARCO HOYLE, R., 1948 - Cronología Arqueológica Del Norte Del Perú, 87 pp.; Buenos Aires: Sociedad Geográfica Americana. 
LAU, G. F., 2004 - Object of Contention: An Examination of Recuay-Moche Combat Imagery. Cambridge Archaeological Journal, 14 (2): 163-184.

McClelLAND, D. \& DONNAN, C., 2007 - Moche Fineline Paintings from San José De Moro, 199 pp.; Los Ángeles: Regents of the University of California.

PANOFSKY, E., 1955 - The History of Art as a Humanistic Discipline. In: Meaning in the Visual Arts: 1-54; Chicago: University of Chicago Press.

PARDO TOMÁS, J., 2003 - Physicians' and Inquisitors' Stories? Circumcision and CryptoJudaism in Sixteenth-Eighteenth-Century Spain. In: Bodily Extremities (F. Egmond \& R. Zwijnenberg, eds.): 168-194; Burlington, VT: Ashgate.

PÉREZ BOCANEGRA, J., 1631 - Ritual Formulario, E Institucion De Curas, Para Administrar a Los Naturales De Este Reyno, Los Sanctos Sacramentos Del Baptismo, Confirmacion, Eucaristia, Y Viatico, Penitencia, Extremauncion, Y Matrimono: Con Aduertencias Muy Necessarias; Lima: Por Geronymo de Contreras.

QUILTER, J., 2002 - Moche Politics, Religion, and Warfare. Journal of World Prehistory, 16 (2): 145-195.

QUILTER, J., 2008 - Art and Moche Martial Arts. In: The Art and Archaeology of the Moche: An Ancient Andean Society of the Peruvian North Coast (S. Bourget \& K. L. Jones, eds.): 215-228: Austin: University of Texas Press.

SCHER, S. E. M., 2001 - Moche «Erotic» Art: Fertility and Ritual in Pre-Columbian Peru, 354 pp.; New Mexico: New Mexico State University.

SCHER, S. E. M., 2010 - Clothing Power: Hierarchies of Gender Difference and Ambiguity in Moche Ceramic Representations of Human Dress, C.E. 1-850. Dissertation, Emory University.

SØRENSEN, M. L., 1997 - Stig. Reading Dress: The Construction of Social Categories and Identities in Bronze Age Europe. Journal of the European Association of Archaeologists, 5 (1): 93-114.

WEISMANTEL, M., 2004 - Moche Sex Pots: Reproduction and Temporality in Ancient South America. American Anthropologist, 106 (3): 495-505. 